\title{
Groundwater modelling quality in the cold region of the Athabasca River Basin
}

Tesfa Worku Meshesha ${ }^{1,2}$, Junye Wang ${ }^{1, *}$, Nigus Demelash Melaku${ }^{1}$, Cynthia N. McClain ${ }^{2}$

${ }^{1}$ Athabasca River Basin Research Institute (ARBRI), Athabasca University, 1 University Drive, Athabasca, Alberta T9S 3A3, Canada

${ }^{2}$ Debre Berhan University (DBU), Department of Water Resources and Irrigation Management, PoBox.91

${ }^{2}$ Resource Stewardship Division, Alberta Environment and Parks, 3535 Research Road NW, Calgary, Alberta T2L 2K8, Canada

*Corresponding author.

E-mail.com: junyew@athabasca.ca 


\begin{abstract}
Groundwater is a vital resource for human welfare. However, due to various factors, groundwater pollution is one of the main environmental concerns facing. Yet, it is challenging to simulate groundwater quality dynamics due to the insufficient representation of nutrient percolation processes in the soil and Water Assessment Tool model. The objectives of this study were extending the SWAT module to predict groundwater quality. The results proved a linear relationship between observed and calculated groundwater quality considering $\mathrm{No}_{3}$ and TDS with $\mathrm{R}^{2}$, NSE and PBIAS values in the satisfied ranges, albeit underestimation and overestimation were observed due to limited data availability. These results highlight that nitrate and TDS concentrations and variability in groundwater may used as a tool in surface water quality that have to be assumed for designing adaptive management scenarios. Hence, extended SWAT model could be a powerful tool for future regional to global scale modelling of nutrient loads supporting effective surface and groundwater management.
\end{abstract}

Keywords: groundwater quality; extended SWAT model; water quality parameters; Athabasca River Basin

\title{
1. Introduction
}

Groundwater is a vital resource for sustainable social and economic development around the world $[1,2]$. Stored groundwater is generally purified and filtered during infiltration through natural soils and sediments $[3,4]$. Therefore, the quality and quantity of groundwater storage tends to be more stable than surface water. Thus, majority of people in the world primarily depend on groundwater for drinking water [5]. Groundwater offers drinking water for $>1.5 \mathrm{~b}$ people and supports approximately $40 \%$ of agriculture in the form of irrigation [6]. Therefore, protecting groundwater resources, including efficient use and conservation measures, are an important strategy of water resources plan in both developing and developed countries.

However, natural processes, anthropogenic activities, and climate change significantly influence the quality and quantity of groundwater. In various area of the world watersheds, lakes, rivers, wetlands and the associated ecosystems have experienced impacts; thus, the vitality, availability, quality and quantity of these water resources face serious threats. Elevated concentrations of chemical elements and biological constituents exist in the environment, and depending on geo-environmental backgrounds, water pollutants may exhibit spatial and temporal variations $[7,8,9]$. Anthropogenic processes, such as discharge of untreated sewage water to water 
bodies, fertilization, and over exploitation, have changed groundwater quantity and quality [10], leading to soil-water and air pollution [11]. For example, excess application of chemical fertilizer could result in groundwater contamination [12, 13]. Nitrogen leaching, namely the downward transport and percolation of nitrate from the rootzone to the soil layers is one of the aggravating causes for groundwater contamination, especially in irrigated areas [14]. However, it is still unclear how the anthropogenic and natural factors drive the change in the fluxes and storages of water, and associated groundwater quality. Consequently, a linked understanding of surface water and groundwater quality over space and time is critical for the assessment and management of such vital resources and ecosystems services, particularly in arid and semi-arid regions $[4,15,16]$. Since domestic, industrial, agricultural, and other uses can affect the chemical and physical characteristics of groundwater $[10,12]$.

Groundwater assessment is complex, involving identification of surface and groundwater quality and quantity drivers and the occurrence, interaction and determination of the probability of the occurrence of such problems $[17,18]$. In order to simulate both saturated and unsaturated water flow from the porous media, many widely used physical models of recharge equations has been used by [19, 20]. This approach is could capture the groundwater dynamics [20] but lacks representation of land surface information like vegetation cover. In order to address this limitation, scientists have developed various hydrological models to simulate interactions among water, soil, and vegetation. [21] modified the SWAT model to calculate lateral and vertical flows through soil layers to improve representations recharge of groundwater mountain region of Germany. [22] applied the modified SWAT model to simulate the change of soil moisture into groundwater and stream flow in the Muscatatuck River watershed. [23] incorporated a groundwater module in the SWAT model version 2000 to simulate groundwater evaporation in the Yellow River basin. [24] modified the SWAT groundwater module version 2005 to improve infiltration process from sinkholes to surface waters and to simulate aquifer recharge in karst surroundings of the USA. [25, 26 incorporated an algorism to consider the effect of slope and aspect on incoming solar radiation into the SWAT model in the forested watershed in the Boreal plain. [27] Modified the evapotranspiration in the SWAT model to account for two-way groundwater-surface water movement in estimating the groundwater table in Lethbridge and Barons area. [28] Extended the hydrological model for cold climate regions in order to quantify bacterial fluxes and its effect on surface water quality, and [29] evaluated water quality consequently effect on aquatic 
environment. $[30,31,32]$ coupled the SWAT model with the three-dimensional groundwater flow model (MODFLOW) to represent groundwater flow. The main drawback of the coupled model is that the users must establish numerously formatted variables that properly fit [33]. Although these coupled SWAT-MODFLOW models enable simulation of groundwater recharge, aquifer evapotranspiration and groundwater levels, it is a big challenge to find a way to dynamically simulate water quality when coupling SWAT source code with MODFLOW code because the two models may have different definitions, formats and arrays of water quality variables. Therefore, such a coupled approach of the two different models requires modification of core codes, such as definitions of variables and its arrays, to be appropriate for simulating ground water quality [34]. Although a plethora of models have been developed in the past few decades, most of the modelling experiences have focused mainly on understanding on the spatio-temporal groundwater storage. Appraisal of distribution and mitigation of chemical elements in the groundwater using SWAT model is still lacking [5].

Economic activity and human settlement in the Athabasca river basin (ARB) are being varied, and the basin is culturally vibrant and diverse as the homes for more than 150,000 residents with $13 \%$ of Aboriginal peoples [35]. However, increasing the growth and intensification of urban development, agriculture, recreation, forestry, conventional and in situ oil and gas, as well as mining can negatively affect the health of the river basin. Developing reliable groundwater quality model as a tool could provide a very useful insight on the transport and potential mitigation of nonpoint source pollution into groundwater in river basins, which are especially important in assessing the pervasive high nutrients loadings from fertilization and manure application. The main objectives of this study are to: (i) integrate a groundwater nutrient module for nitrate $\left(\mathrm{NO}_{3}\right)$ and total dissolved solid (TDS) in the SWAT model for the Athabasca River Basin; (ii) assess the effect to $\mathrm{NO}_{3}$ and TDS on groundwater quality status; and (iii) evaluate SWAT model sensitivity and uncertainty analysis to understand the possible limitations, and recommend forthcoming directions in model formulation efforts.

\section{Methods and Materials}

\subsection{The study area}

The research has performed in ARB, which is found in the central part of the province of Alberta as shown in Fig. 1. The area is a cold climate region. The river basin in general have substantial economic contribution for the area by providing reliable water supply to the people as 
well as for various industries, such as oil sands mining and pulp mills [36]. The main land cover type of the ARB is forest, which shared $82 \%$ of the total land; agriculture share took $9.5 \%$, which is located in the central portion of the watershed (i.e., Pembina, Lesse Slave, McLeod and upper parts). Overall forest, agriculture, traditional oil and gas extraction, oil sand mining, and coal mining are the major industries of ARB [35]. Mean annual precipitation of the area ranges from $300 \mathrm{~mm}$ in the lower portion of the river basin to $>1000 \mathrm{~mm}$ at the headwaters, while the mean temperature $1.8^{\circ} \mathrm{C}-5.1^{\circ} \mathrm{C}[37]$.

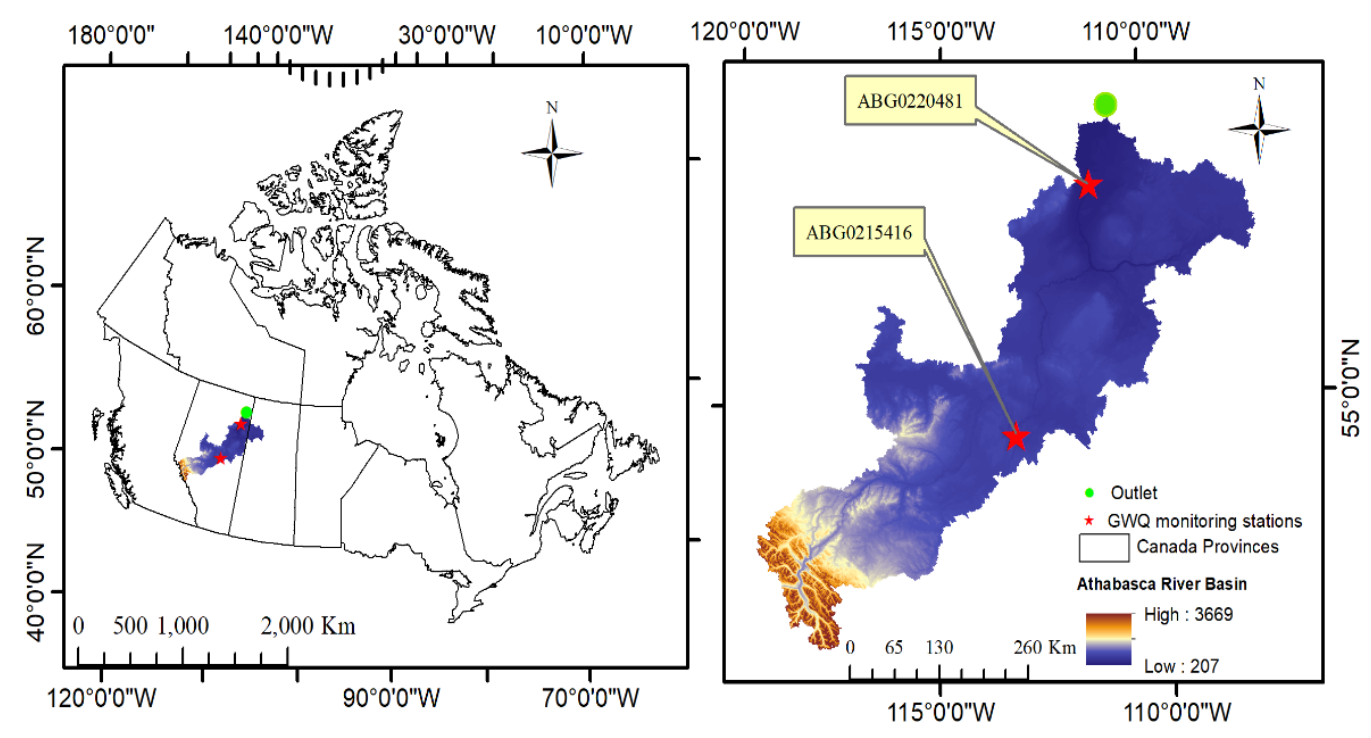

Fig. 1. Geographical location of Athabasca River Basin (ARB), Canada. The DEM (m) of the ARB shows the two water quality monitoring stations used for model calibration for this study.

The following major aquifer types, viz., near-surface sands, buried channels and valleys, Paskapoo aquifers, and bedrock aquifers characterize the basin with primary and/or secondary porosity [36]. Groundwater contributions to stream flow in the Athabasca River are also mentioned in reference to Instream Flow Needs assessments [38]. In-situ oil sands operations typically occur where soil sand deposits are present at the depth, which is greater that $150 \mathrm{~m}$ deeper, and the main types of operations exists in the southern Athabasca Oil Sands region. In the area, groundwater continues within unconsolidated surficial deposit consist of a mixture of preglacial and glacial sand and gravel aquifer.

\subsection{Soil and Water Assessment Tool (SWAT) description}

The SWAT model is a river basin scale model, which is developed in order to quantify the impact of land management practices in large, complex watersheds that operates on a continuous daily time step [39, 40]. It is employed to simulate the hydrological process, nutrient concentration, 
runoff generation, and sediment yield in the watershed under various landuse as well as soil scenarios [39, 41, 42]. Additionally, it is used for simulating the effects of climate change, landuse and management practices on the quantity and quality of water [43].

\subsection{Soil and Water Assessment Tool Application}

SWAT model can simulate the $\mathrm{N}_{2}$ cycle of soil profile and in the aquifer at shallow depth $[44,45]$. In the water and soil, the condition of $\mathrm{N}_{2}$ is very exists in a various form of dynamics. It could be added to the soil in the form of manure, bacteriological fixation, residue, and rainfalls. It may be detached from the soil through by plant uptake, volatilization, soil erosion, denitrification, and leaching. In SWAT model, there are various types of pools of $\mathrm{N}_{2}$ in the soils. Some are inorganic forms of $\mathrm{N}_{2}$, and other pools are organic forms of $\mathrm{N}_{2} . \mathrm{NO}_{3}$ may transport with runoff, percolation or lateral flow. It recharges into the aquifer to the shallow depth from the soil profile in the form of percolation. It would be moved with the groundwater flow through main channel. Letter moved out of the shallow aquifer with water moving into the soil zone during water deficiencies and hence recharge into deep aquifer. The amount of nitrate carried by the water is obtained by multiplying the concentration of nitrate in the mobile water by the volume of water moving in each route. The discharge of $\mathrm{NO}_{3}{ }^{-}$into the tiles is depend on $\mathrm{NO}_{3}{ }^{-}$concentration in the soil-water near the tiles. The first level of nitrate, which has the initial form of $\mathrm{N}_{2}$ that uptake by plants, have inverse exponential relationship with the depth [40].

$$
N O_{3 \text { conc }, z}=7 * \exp \left(\frac{-z}{1000}\right)
$$

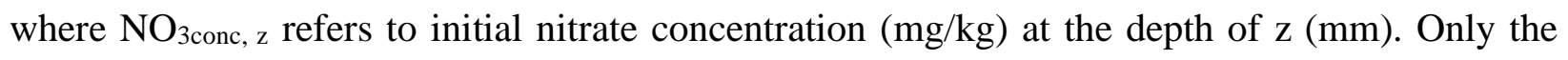
parts of $\mathrm{NO}_{3}{ }^{-}$is mobile and therefore it available for the discharge through the tiles. To calculate the concentration of nitrate in the mobile water fraction, the following equation has been adopted from $[46,47]$.

$$
\operatorname{Conc}_{\mathrm{NO}_{3}, \text { mobile }}=\frac{N O_{31 y}\left(1-\exp \left[-W_{\text {mobile }} /(1-\theta e) S A T_{1 y}\right]\right)}{W_{\text {mobile }}}
$$

where $\mathrm{ConcN} \mathrm{N}_{\mathrm{O}}$, mobile refers to $\mathrm{NO}_{3}{ }^{-}$concentration in the movable water at a given layer $(\mathrm{kg} \mathrm{N} / \mathrm{ha})$, $\mathrm{W}_{\text {mobile }}$ represent the amount of water lost by runoff, percolation or side flow in the layer (mm $\mathrm{H}_{2} \mathrm{O}$ ), $\theta e$ represent fraction of porosity from which anions are excluded, $\mathrm{SAT}_{1 \mathrm{y}}$ is saturated water content in the soil layer $\left(\mathrm{mm} \mathrm{H}_{2} \mathrm{O}\right)$. To obtain the transport of nitrate with runoff, percolation, and lateral flow, the following generic equation has been adopted form [48]. 


$$
\mathrm{NO}_{3}=\beta_{\mathrm{NO}_{3}} \operatorname{conc}_{\mathrm{NO}_{3}, \text { mobile }} Q_{x}
$$

where, $\mathrm{NO}_{3}$ represent the $\mathrm{NO}_{3}{ }^{-}$removed by the physical transport mechanisms consider (lateral flow, runoff, percolation)/kg ha- $1 ; \beta \mathrm{NO}_{3}$ is the concentration of $\mathrm{NO}_{3}{ }^{-}$in the mobile water for the top $10 \mathrm{~mm}$ of soil $/ \mathrm{kg}$ ha- 1 considering both surface and subsurface lateral flow in the top layer; and $\mathrm{Q}_{\mathrm{x}}$ is the physical transport mechanism considered (i.e. $\mathrm{Q}_{\text {surf }}, \mathrm{Q}_{\text {lat }}, \mathrm{Q}_{\text {perc }}$. $\mathrm{NO}_{3}{ }^{-}$percolating to the shallow aquifer from the soil profile may store in the aquifer or move with groundwater flow into the main channel or to the shallow aquifer and recharge the deep aquifer. Organic transport of $\mathrm{N}$ with sediment is obtained as a concentration function proposed by [49] and letter employed by [9] for the application of separated runoff events. Estimation of the daily organic $\mathrm{N}$ runoff loss is on the basis of concentration of organic $\mathrm{N}$ in the topsoil layer, the sediment yield as well as the enrichment ratio: that of the organic nitrogen in sediment to organic $\mathrm{N}$ in soil layer [44] (see Fig. 2). In the SWAT model, water quality procedures integrate essential interactions and relationships used in the QUAL2E model [50], which includes the major interactive factors such as the nutrient cycles, benthic oxygen demand, and algae production.

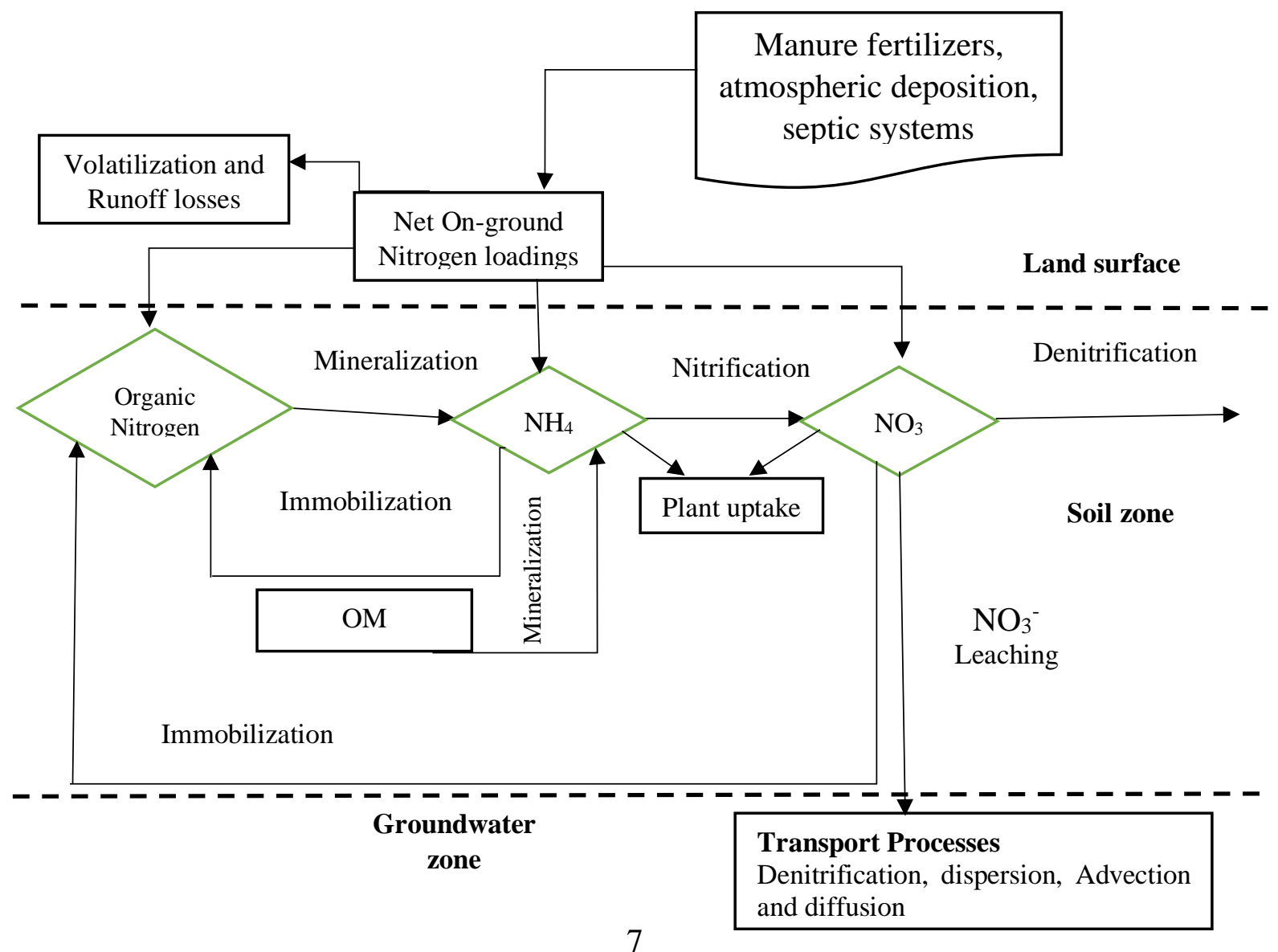


Fig. 2. The conceptual framework demonstrating nitrate occurrence in the groundwater (adopted from [51].

TDS shows all dissolved chemicals in the water, which is expressed as $\mathrm{mg} / \mathrm{L}$, can be obtained by adding all the concentrations from chemical analysis or can be measured as weight of the residue after a volume of water has been evaporated to dryness. Typically, the concentration of TDS increases with the sample depth that groundwater has traveled from the recharge area to the sample sites. High nutrient concentration in the groundwater shows contamination form different sources of pollution [52].

\subsection{Groundwater module in the SWAT model}

Existing SWAT model dividers underground saturated aquifer into shallow as well as deep aquifer. As per $[40,53]$, the balance of water the shallow aquifer can be obtained as follows:

$$
S_{s h}^{i}=S_{s h}^{i-1}+W_{r g, s h}^{i}-Q_{g w, s h}^{i}-W_{r p}^{i}-W_{p u m p, s h}^{i}
$$

where, $S_{s h}^{i}$ and $S_{s h}^{i-1}$ is the volume of water stored in the shallow aquifer on the day i and i-1,

respectively, $Q_{g w, s h}^{i}$ is refers to the groundwater from the shallow aquifer on the day $i, W_{r g, s h}^{i}$ shows the volume of recharge which is entering the shallow aquifer on the day $i, W_{r p}^{i}$ is indicates the amount of water entering to the soil for the evaporation as well as transpiration on the day $i$, $W_{\text {pump,sh }}^{i}$ is refers to the amount of water removed from the shallow aquifer in the form of pumping on the day $i$. Assuming the there is no pumping and no re-evaporation, is employed to calculate the flow of groundwater using the following equation:

$$
Q_{g w, s h}^{i}=\alpha_{g w, s h} S_{s h}^{i}
$$

where, $\alpha_{g w, s h}$ refers to the groundwater recession constant of the shallow aquifer. From groundwater from the shallow aquifer contributed for stream on the day $i$ is obtained as:

$$
Q_{g w, s h}^{i}=Q_{g w, s h^{\alpha_{g w, s h}}}^{i-1}+W_{r g, s h}^{i}\left(1-e^{-\alpha_{g w, s h}}\right)
$$

The volume of recharge entering to the shallow aquifer on the day $i$ is obtained using the following equation:

$$
W_{r g, s h}=\left(1-\beta_{d p}\right) W_{r g}^{i}
$$




$$
\begin{aligned}
& W_{r g}^{i}-\left(1-e^{-\frac{1}{\delta_{g w, s h}}}\right) W_{\text {seep }}+e^{-\frac{1}{\alpha_{g w, s h}}} W_{r g}^{i-1} \\
& W_{r g, \text { deep }}=\beta_{d p} W_{r g}^{i}
\end{aligned}
$$

where, $W_{r g}^{i}$ and ${ }_{W_{r g}^{i-1}}^{i-}$ refers the volume of recharge which is entering into the aquifers (onto both shallow and deep) on the day $i$ and $i$-1 respectively, $\delta_{g w, s h}$ refers to the coefficient that shows the delay time of the recharge for the shallow aquifer, $W_{r g, \text { dee }}$ shows the volume of water exiting the bottom of soil profile on the day $i$, and $\beta_{d p}$ shows the coefficient which reflects the volume of water percolated into deep aquifer. Likewise, from the deep aquifer groundwater, which is contributed to the stream on the day, $i$ is obtained by:

$$
Q_{g w, \text { deep }}^{i}=Q_{g w, \text { deep }}^{i-1} e^{-\alpha_{g w, d e p}}+W_{r g, \text { deep }}^{i}\left(1-e^{-\alpha_{g w, d e p}}\right)
$$

In order to represent better simulation results of groundwater modelling, we adopted equation 6 as follows:

$$
\begin{aligned}
& Q_{g w, u}^{i}=Q_{g w, u^{e}}^{i-1}{ }^{-\alpha_{g w, u}}+W_{r g, u}^{i}\left(1-e^{-\alpha_{g w, u}}\right) \\
& Q_{g w, l}^{i}=Q_{g w, l^{-\alpha_{g w}, l}}^{i-1}+W_{r g, l}^{i}\left(1-e^{-\alpha_{g w}, l}\right)
\end{aligned}
$$

where, $\boldsymbol{Q}_{s w, l}^{i}$ and $\boldsymbol{Q}_{s w, u}^{i}$ refers to flow of groundwater from lower and upper aquifer into the stream on the day $i$ respectively; where as $-\alpha_{g w, u}$ and $-\alpha_{g w, l}$ shows groundwater recession constant of the lower and upper aquifer respectively; $\boldsymbol{W}_{r g, l}^{i}$ and $\boldsymbol{W}_{r g, u}^{i}$ shows the volume of recharge entering into the lower and upper aquifer in the day $i$ respectively.

\subsection{SWAT model setup}

The study are delineation processes were done in ArcGIS. Based on soil types and landuse classes the hydrological response unit was defined. Therefore, based on similar soil, similar landuse, and slope types, about 1370 HRU were identified for the basins. Weather data viz., temperature, rainfall, wind speed, humidity, and radiation observation were obtained from Alberta Environment and Parks. Groundwater well and water quality data (nitrogen species and TDS) for 
1,300 different monitoring stations was obtained from Alberta Environment and Parks as shown in Fig. 1. Data availability is one of the most prominent factors, which affect the model accuracy. Therefore, there were two monitoring stations with $>15$ samples for the selected parameters between 1986 and 2003 namely Petro Canada Main Camp GOWN \#256 (ABG0215416), House River 2193E GOWN\#207 \& House River 2194E (NE) GOWN \#257 (ABG0220481).

\subsection{Model performance Metrix analysis}

Measured daily groundwater quality data $\left(\mathrm{NO}_{3}^{-}\right.$and TDS) obtained from Alberta, Environment and Parks and were used for the model calibration and validation. Model simulation performances were compared in relation to observed data. In order to perform parameter sensitivity and uncertainty analysis, we used Sequential Uncertainty Fitting2 (SUFI-2) algorithm in the SWAT-CUP [54]. In SWAT-CUP, sensitivity analysis has been used for model sensitivity analysis. To examine the effect of $\mathrm{NO}_{3}{ }^{-}$and TDS on groundwater quality, parameters have been chosen and considered during calibration and validation. To evaluate model performance, $\mathrm{R}^{2}$, PBIAS and NSE were used [55]. The descriptions of NSE, $\mathrm{R}^{2}$, and PBIAS can be found in [56]. The overall model performance evaluations obtained as follows:

$$
\begin{aligned}
& R^{2}=\left(\frac{\sum_{i=1}^{n}\left(O_{i}-O_{a v r}\right)\left(P_{i}-P_{a v r}\right)}{\sqrt{\sum_{i=1}^{n}\left(O_{i}-O_{a v r}\right)^{2}} \sqrt{\sum_{i=1}^{n}\left(P_{i}-P_{a v r}\right)^{2}}}\right)^{2} \\
& \text { NSE }=1-\left[\frac{\sum_{i=1}^{n}\left(O_{i}-P_{i}\right)^{2}}{\left[\sum_{i=1}^{n}\left(O_{i}-O_{a v r}\right)^{2}\right]}\right] \\
& \text { PBIAS }=\left[\frac{\left.\sum_{i=1}^{n} O b s_{i}-S_{i m}\right)^{*} 100}{\sum_{i=1}^{n} O_{\text {Obs }}}\right]
\end{aligned}
$$

where $\mathrm{O}_{\mathrm{i}}$ refers to the $\mathrm{i}^{\text {th }}$ observed value; $\mathrm{O}_{\mathrm{avr}}$ is the average observed value; $\mathrm{P}_{\mathrm{i}}$ is the $\mathrm{i}^{\text {th }}$ simulated value; $\mathrm{P}_{\mathrm{avr}}$ is average simulated value; $\mathrm{n}$ is the number of time steps (days in our case). 


\section{Results and Discussion}

\subsection{Performance of the modified bacteria module in SWAT model}

To check our modified groundwater module, the SWAT model should be calibrated and validated for the stream flow, temperature, and sediment load. These have been done in our previous work. The interested readers can check for references, such as stream flow [38], temperature [57], and sediment [43]. In this paper, we, therefore, focus on the calibration and validation of groundwater quality modelling.

\subsection{Sensitivity and uncertainty analysis}

In order to perform performance assessment, the entire dataset was divided into the periods of calibration and validation. Prior to model calibration and validation processes, sensitivity test analysis has been done to identify the most sensitive parameters that govern $\mathrm{NO}_{3}{ }^{-}$and TDS. Some parameter are basin scale and others are basin based parameters. The analysis of model sensitivity can be processed to find out the relative response of the SWAT model to the changes in relative value of specific model parameters. Hence, model sensitivity analysis is employed to decide the most significant parameters that control the whole system processes. To simulate the modified SWAT model, the most sensitive parameters governing the groundwater parameters were assessed on the basis of the values obtained during primary model calibration. The CDN.bs, r__GWNO $3 . g w$, HLIFE_NGW.gw, and NPERCO.bsn are the most sensitive parameters among the $\mathrm{NO}_{3}$ parameters. While NSETLR1.1wq and N_UPDIS.bsn are the sensitive parameters from the $\mathrm{N}_{2}$ parameters, that influence the concentration. On the other hand, parameters listed in Table 1 are the most sensitive parameters for TDS, groundwater conditions, and surface runoff. The parameters shown in Table 1 were considered as the most sensitive parameters. The results of the sensitive analysis confirmed that measured input parameters have a substantial influence on the model prediction.

To calibrate the model, the simulated outputs were compared with observed value. Therefore, the daily $\mathrm{NO}_{3}{ }^{-}$and TDS from the groundwater monitoring stations ABG0215416 and ABG0220481 from ARB were employed for the model calibration and validation to evaluate the model performance. The range of selected sensitive parameters are presented in Table 1. To 
calibrate the modified SWAT module, Latin-Hypercube One-factor At a Time (LH-OAT) was employed.

Table 1. The ranges of parameters included prior and after model calibration.

\begin{tabular}{|c|c|c|c|c|c|}
\hline Parameters & input & Description & Unit & Range & $\begin{array}{l}\text { Fitted } \\
\text { value }\end{array}$ \\
\hline Denitrification & CDN.bs & $\begin{array}{l}\text { Denitrification exponential rate } \\
\text { coefficient }\end{array}$ & NA & $0-3$ & 2.5 \\
\hline Ground W. Nitrn. & $\mathrm{r} \_$GWNO3.gw & $\begin{array}{llll}\begin{array}{l}\text { Concentration } \\
\text { groundwater }\end{array} & & \mathrm{NO}_{3} & \text { in } \\
& & \end{array}$ & & $-1-1$ & 0.5 \\
\hline Nitrate Percoln. co & NPERCO.bsn & Nitrate percolation coefficient & & $0-1$ & 0.223 \\
\hline $\begin{array}{l}\text { Transport of } \\
\text { nitrogen growth } \\
\text { with sediment }\end{array}$ & ERORGN.hru & Organic nitrogen enrichment ratio & NA & $0-5$ & 2.75 \\
\hline $\begin{array}{l}\text { Shallow aquifer } \\
\text { nitrate }\end{array}$ & HLIFE_NGW.gw & $\begin{array}{l}\text { Half-life of nitrate-nitrogen in the } \\
\text { shallow aquifer }\end{array}$ & Day $^{-1}$ & $0-200$ & 116 \\
\hline Mineralization & CMN.bsn & $\begin{array}{l}\text { Rate factor for } \\
\text { mineralization of active } \\
\text { nitrogen }\end{array}$ & NA & $\begin{array}{l}0.0001- \\
0.0003\end{array}$ & 0.000131 \\
\hline $\begin{array}{l}\text { Nitrogen } \\
\text { percolation }\end{array}$ & NPERCO.bsn & Percolation of Nitrogen coefficient & NA & $0-1$ & 0.5 \\
\hline $\begin{array}{l}\text { Nitrogen settling } \\
\text { rate }\end{array}$ & NSETLR1.1wq & Settling Nitrogen rate & $\mathrm{m} /$ year & $1-150$ & 30 \\
\hline $\mathrm{N}_{2}$ uptake & N_UPDIS.bsn & $\begin{array}{l}\text { Distribution of Nitrogen uptake } \\
\text { parameter }\end{array}$ & NA & $1-31$ & 28 \\
\hline Base flow & RCHRG_DP.gw & $\begin{array}{l}\text { Groundwater recharge to deep } \\
\text { aquifer }\end{array}$ & fr & $0-1$ & 0.09 \\
\hline Base flow & REVAPMN.gw & Water depth in the shallow aquifer & $\mathrm{mm}$ & $0-500$ & 196 \\
\hline Base flow & GW_DELAY.gw & Groundwater delay & $\mathrm{d}$ & $0-500$ & 41 \\
\hline Base flow & GWQMN.gw & $\begin{array}{l}\text { Threshold depth of water in the } \\
\text { shallow aquifer required fir return } \\
\text { flow to occur }\end{array}$ & $\mathrm{mm}$ & $0-1000$ & 618 \\
\hline Base flow & GW_REVAP.gw & Groundwater revap coefficient & NA & $0.02-2$ & 0.06 \\
\hline $\begin{array}{l}\text { Lateral } \\
\text { flow/infiltration }\end{array}$ & SOL_K.sol & hydraulic conductivity (Saturated) & $\mathrm{Mmh}^{-1}$ & $\begin{array}{l}-25- \\
+25\end{array}$ & 16 \\
\hline $\begin{array}{l}\text { Lateral } \\
\text { flow/infiltration }\end{array}$ & SOL_AWC.sol & $\begin{array}{l}\text { water capacity of the soil layer } \\
\text { (Availability) }\end{array}$ & $\mathrm{ft}$. & $\begin{array}{l}-25- \\
+25\end{array}$ & 10 \\
\hline
\end{tabular}




\begin{tabular}{llllll} 
runoff & CN2.mgt1 & curve number for moisture condition & NA & $-15-$ & 10 \\
& & II & & +15 & \\
runoff & CH_N1.sub & Manning's rate for tributary channel & NA & $0.025-$ & 0.096 \\
& & & 0.30 & \\
Base flow & ALPHA_BF.gw & Base flow alpha factor & d & $0-1$ & 073 \\
\hline
\end{tabular}

\subsection{Model Calibration and Validation performance}

Model calibration and validation are done after the sensitivity analysis. Here, we calibrated and validated the model automatically in SWATCUP, which was recommended by [58], using groundwater quality data obtained from groundwater monitoring stations at two locations. Table 2 summaries the performance statistics of the model for the daily nutrient concentration simulations for two stations. To effectively calculate the concentration of $\mathrm{NO}_{3}{ }^{-}$, and TDS in the groundwater and related effect on groundwater quality, the status as simulated by the extended SWAT model essentially assured to what is the watershed status. Hence, the daily observed data from two groundwater observation stations were used for the model calibration and validation to assess the model performance. Based on the criteria of model performances rating, the value of PBIAS, NSE and $\mathrm{R}^{2}$ during model calibration and validation shows satisfactory to very good for both stations, confirming that the model was able to capture the concentration of nutrients after model modification (Table 2 and Fig. 3). Therefore, the overall model performance for the daily nutrient concentration simulations in the ARB for the two stations by the new SWAT module evaluated as in acceptable range of model calibration and validation. Albite lower model performance for TDS simulation was observed at monitoring station ABG0220481, in which the value of NSE is found to be 0.37 .

Table 2. Model performance assessment for the daily observed data.

\begin{tabular}{llcccc}
\hline Monitoring & Performance & \multicolumn{3}{c}{$\mathrm{NO}_{3}$} & \multicolumn{2}{c}{ TDS } \\
\cline { 3 - 6 } stations ID & measure & Calibration & Validation & Calibration & Validation \\
\hline ABG0215416 & NSE & 0.65 & 0.72 & 0.80 & 0.55 \\
& PBIAS & 2.68 & 3.41 & -2.21 & 0.43 \\
& $\mathrm{R}^{2}$ & 0.69 & 0.66 & 0.81 & 0.66 \\
ABG0220481 & NSE & 0.85 & 0.73 & 0.37 & 0.66 \\
& PBIAS & 5.44 & 8.02 & 5.36 & 7.5 \\
& $\mathrm{R}^{2}$ & 0.85 & 0.70 & 0.59 & 0.69 \\
\hline
\end{tabular}




\subsection{Calibration of Nitrate and assessment}

Nitrate calibration processes happened in a nitrogen percolation coefficient of 0.5 , hence a denitrification threshold of water content and exponential rate of denitrification coefficient of 2.5 (Table 1). Nitrate percolation coefficient (0.223) and half-life parameter of nitrate in the shallow aquifer (116) were calibrated for each sub-basin for the values in the range of 0-1 and 0-200 day1 respectively, resulting in 0.223 and with the mean value of 116 day $^{-1}$ respectively for the whole selected ARB. The annual mean nitrification was thus estimated for the selected basin observed around $0.164 \mathrm{mg} / \mathrm{L}$ at station ABG0215416 and $0.116 \mathrm{mg} / \mathrm{L}$ at station ABG0220481 stations (Fig. 3). Since $\mathrm{NO}_{3}$ is one forms of nitrogen, parameters were adjusted that affect $\mathrm{N}_{2}$. Therefore, the processes of mineralization were adjusted by minimizing the default values of the rate factor of CMN to 0.000131 and the percolation coefficient of nitrogen to 0.5. To slow down simulated kinetics, for better controlling the depth distribution of nitrogen uptake the N-UPDIS has been increased the default value from 20 to 28 and therefore large volume of $\mathrm{NO}_{3}$ removed form the upper layers as per the report by [59]. The rate of nitrogen settling in reservoirs were kept steady during the year and as per [60], the range has set greater than the default values as of in the SRB (Sava River Basin), to efficiently simulate the substantial retention of major wetlands not applied in the extended SWAT model.

The nitrification dwindled from upper to lower Athabasca River Basin signifying the rainfall distribution subsequently lower rainfall leads to lower soil saturation then consequently lower nitrification. The maximum values of annual nitrification observed in the ARB found to be $0.46 \mathrm{mg} / \mathrm{L}$ at ABG0215416 and $0.29 \mathrm{mg} / \mathrm{L}$ at ABG022048 stations, whereas the minimum values were $0.012 \mathrm{mg} / \mathrm{L}$ in the ABG0215416 station and $0.001 \mathrm{mg} / \mathrm{L}$ generally observed in the ABG0220481stations. The nitrification calibration resulted to satisfactory predictions of $\mathrm{NO}_{3}$ daily concentration in the two observation stations in the calibration and validation dataset. Ae per the comparison of $\mathrm{NO}_{3}{ }^{-}$between simulated and observed, better model performances were obtained in the model evaluation dataset. On the basis of visual comparison of both calculated and observed daily $\mathrm{NO}_{3}$ concentration (Fig. 3), the concentrations of $\mathrm{NO}_{3}$ were acceptable range as it follows similar trend as the observed values. The percentage BIAS obtained from the observed and calculated daily loads ranked as acceptable to very good for all the selected stations (Fig. 3 and Table 2). 

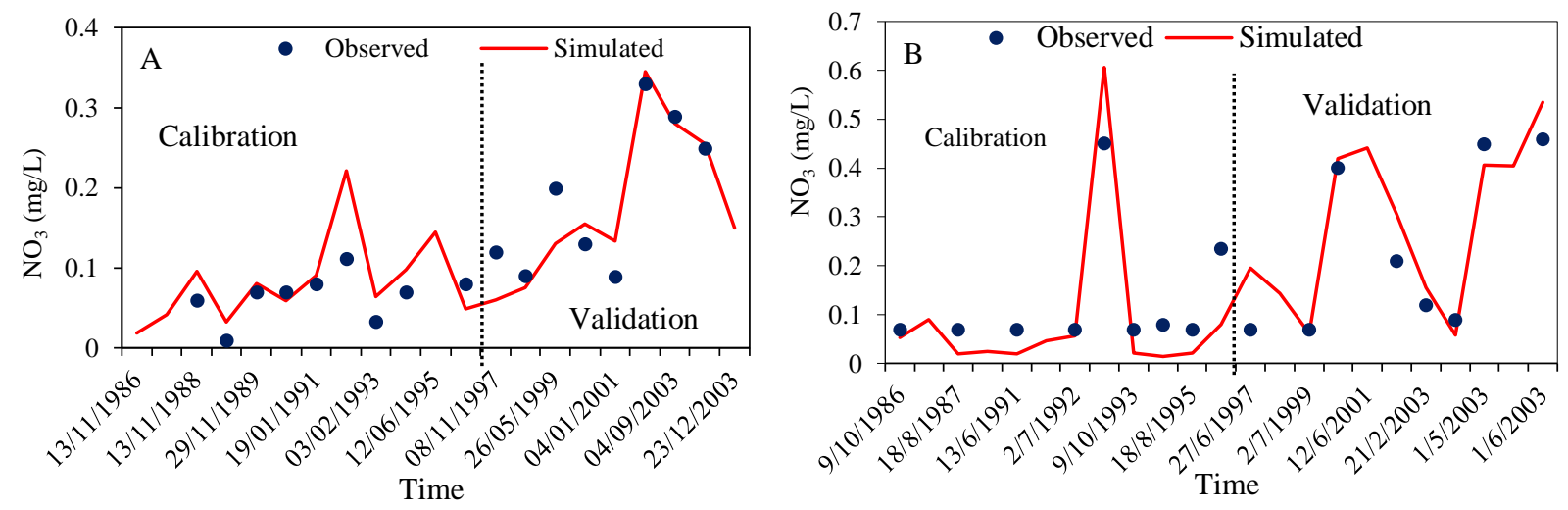

Fig. 3. Comparison of observed and simulated groundwater quality parameter $\left(\mathrm{NO}_{3} / \mathrm{mg} / \mathrm{L}\right)$ at ABG0215416 (A) and ABG0220481 (B) monitoring stations.

\subsection{Total dissolved solids (TDS)}

The development of TDS module for groundwater quality detection using the daily TDS concentration from the selected stations at ARB. The calibrated TDS parameters with specific ranges are presented in Table 1. Daily dissolved solid loads were calibrated by correcting the parameters settling to the groundwater. Some of the considered parameters are found to be HRU scale parameters and while the other parameters are considered to basin and scale parameters, which control groundwater TDS concentration. As per the report by Morias et al., (2015) the model performance evaluation criteria for the daily nutrient simulation were used as guideline to evaluate the model performance for the daily TDS loads. As shown in Fig. 4, for the whole periods of simulation were found to be good to very good. While during the validation satisfactory to good during calibration based on $\mathrm{R}^{2}$, NSE and PBIAS values as indicated using Table 2. Generally, as per the overall model performance evaluation for the daily TDS loads simulations in the ARB shows the model were capable to capture the loads. On the basis comparison between the calculated and observed daily concentrations (Fig. 4), the TDS loads were acceptable as both shows similar trend. Yet, local inconsistencies were noticed through the river basin. The highest percentage of over estimation and underestimation performance for the TDS in the calibration dataset probably reflects the trouble of SWAT model in reproducing high-level concentrations in the measures [61], which in turns may cause errors in process of estimating the TDS in the SWAT model. On the other hand, the lower model performance in simulating the concentration of TDS even after modification probably related to the local errors in process of simulating other fluxes as 
observed in [62]. The other possible sources of overestimation and underestimation of the model simulations were subjected to uncertainties of the input data and observed data.
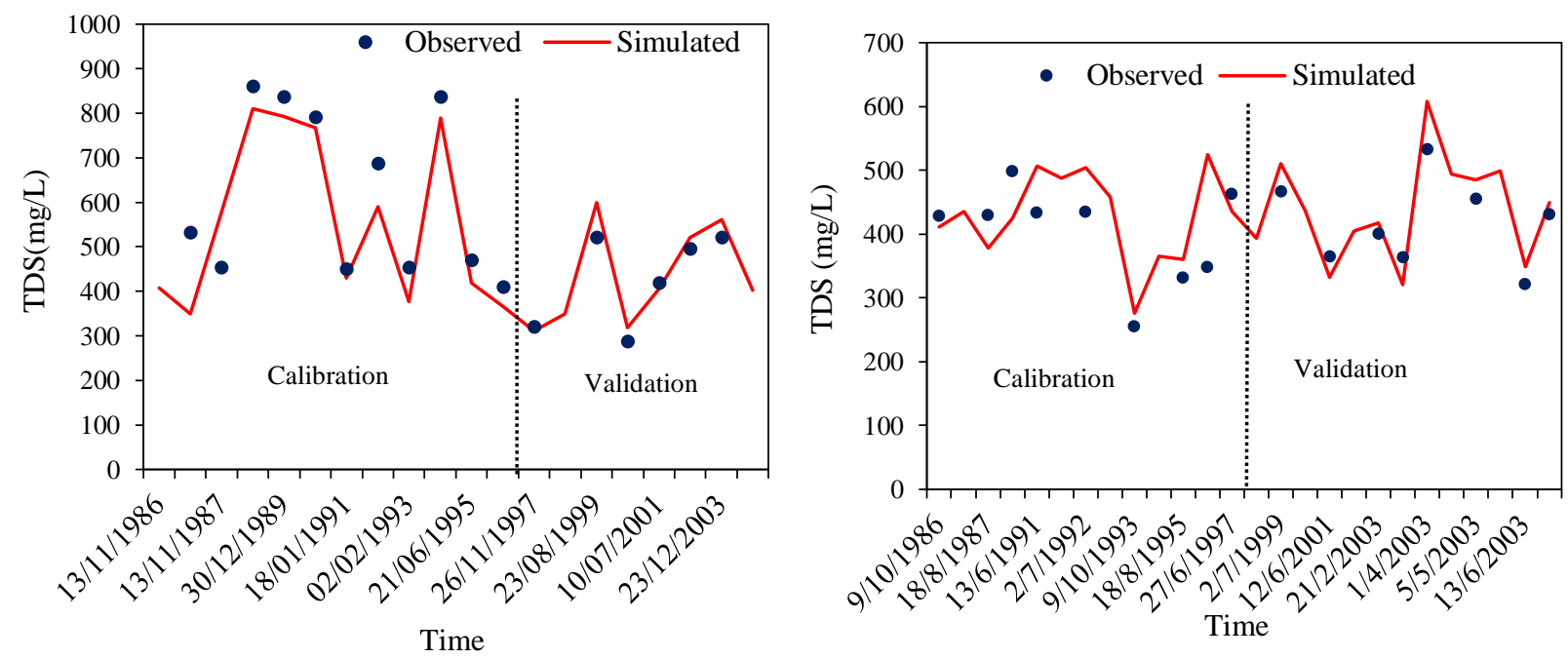

Fig. 4. Comparison of observed and simulated groundwater quality parameter (TDS/mg/L) at ABG0215416 (A) and ABG0220481 (B) monitoring stations.

The TDS is indicator of the availability of total dissolved salt and other parameter that affect the groundwater quality. The availability of high electrical conductivity and observed TDS in the groundwater indicate a downward movement of leachate into the groundwater as per a work done by $[63,64]$. The TDS loads of the groundwater in the study area ranges $528.05 \mathrm{mg} / \mathrm{L}$ to 412.2 mg/L at ABG0215416 and ABG0220481 sampling stations respectively. The total dissolved solids of groundwater samples range $289-862 \mathrm{mg} / \mathrm{L}$ at ABG0215416 station, while the daily TDS ranges 321-533mg/L at ABG0220481 station (Fig. 4). High concentrations of TDS in the groundwater reduce the palatability of water in the ground and may a source cause of gastrointestinal pain in human stomach and emetic effects upon transits [65]. As of TDS is an important indictor for evaluating the quality of groundwater, high level of TDS typically shows hard water and might lead to groundwater treatment, as per WHO standard, the limit for the concentrations of TDS is 500mg/L [65]. 

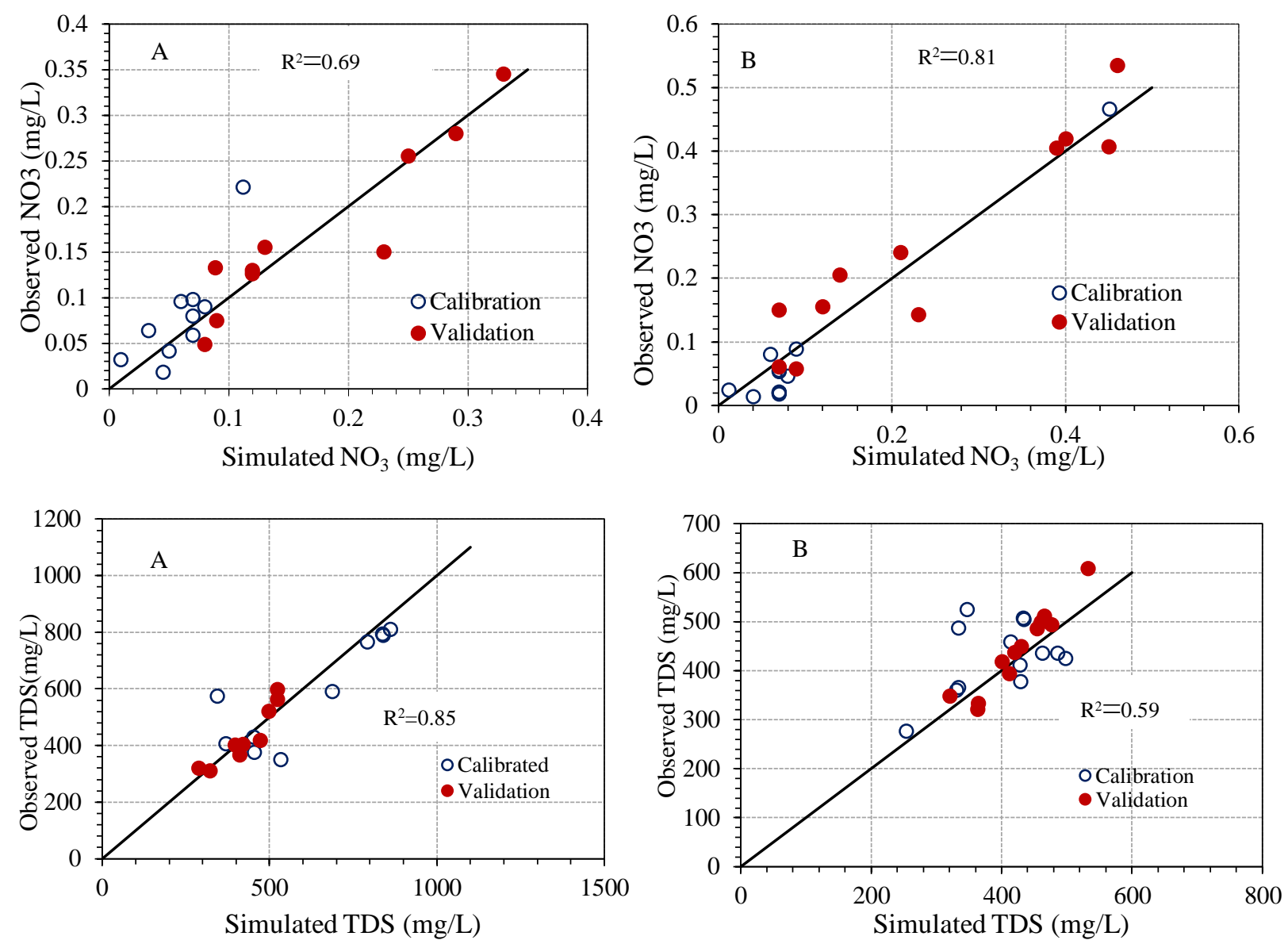

Fig. 5. Scatter plot comparison between of daily simulated and observed groundwater quality parameters at ABG0215416 (A) and ABG0220481 (B) monitoring stations.

The performance of model results were investigated by the analysis of scatter plot between observed and simulated estimates at each groundwater monitoring stations (Fig. 5). The slope selected stations were considerably far from zero concluding the model prediction accuracy was enhanced by extended groundwater model. Thus, the results of the 1:1 fitting line confirmed that the extended groundwater SWAT module effective model predictive power for nutrient concentration in the groundwater during modelling process. The scatters are closer to the 1:1 line for the entire study time at two monitoring stations, albeit at some points relatively far from the fitting line probably due to limited availability of observed data. In general, it is worth to conclude the extended SWAT groundwater module shows better efficiency for nutrient concentrations in the groundwater and help to investigate its quality.

\subsection{Groundwater quality analysis and nutrient fluxes}


Analysis of observed against simulated in the ARB groundwater condition help as to identify sources of errors across the two monitoring stations of the river basin. Daily observed nitrate concentrations vary significantly across the area (Fig. 3). Concentrations of $\mathrm{NO}_{3}$ in the groundwater have been highly effected by emissions of both point and diffused sources in various watersheds across the world [66]. To assess pollution sources and quantify the loads of $\mathrm{NO}_{3}{ }^{-}$ entering the whole river basin, $\mathrm{NO}_{3}{ }^{-}$load in the groundwater has simulated at various hydrological response unit. The simulation periods were chosen based on the availability of point sources information. The long-term daily average concentrations of nitrate in the period 2003 attaining the maximum values in the ABG0215416 station, in which the mean value found to be $0.46 \mathrm{mg} / \mathrm{L}$. While in station, the daily mean value reached the lowest values in the $0.012 \mathrm{mg} / \mathrm{L}$ for the year 1987. On the other hand, at station ABG0220481 the long-term daily average $\mathrm{NO}_{3}$ concentrations recorded a maximum value of $0.29 \mathrm{mg} / \mathrm{L}$ during the year 2003 while attained the lowest value of $0.01 \mathrm{mg} / \mathrm{L}$ during the year 1989. Nitrate is the main component of total nitrogen (which accounts for around $70 \%$ of $\mathrm{TN}$ ) and the concentrations of both nitrate and total nitrogen decrease with increasing the size of the river hence the concentration in the groundwater. Generally, the concentrations of nitrate were well captured in all groundwater-monitoring stations, although overestimations were observed at some points for ABG0215416 monitoring stations (Fig. 3), while underestimations were found in ABG0215416 and ABG0220481 monitoring stations. The probable reason for model overestimation is the data uncertainty such rainfall and snow distribution, in which the rainfall and snow distribution caused in nutrient concentrations. The Underestimation probably subjected to the uncertainty of the input data and measured data. Furthermore, the observed $\mathrm{NO}_{3}$ data is not sufficient for continuous daily $\mathrm{NO}_{3}{ }^{-}$concentration for the entirely considered period for this study. Therefore, observed data could be sources for the errors. In fact, soil denitrification caused excessive $\mathrm{NO}_{3}{ }^{-}$simulation could improved by varying the river basin parameters. However, the existing SWAT model could not represent perfectly the seasonal difference of nitrate. After carefully extending the model, the findings of this study highlight the essential to improve spatial representation of nitrification in the groundwater where its dependability is restricted by setting appropriate parameters at watershed level. Noticeable differences were observed after extending the SWAT model, albeit overestimations and underestimations (Fig. 3) were observed at some points with limited available data. 


\subsection{Uses of SWAT model predictions and future applications}

The SWAT predictions and limitations analysis is associated with data availability and structure of the model, able to offers valuable insights related to groundwater condition and nutrient processes at the various spatio-temporal scale at different time scale (i.e. daily, monthly and annually). This "state of the art" groundwater quality modelling at ARB recognized as a vital spot where further in-depth studies may be required. For examples, to better support, river basin management in the nutrient monitoring network could be strengthened and harmonized monitoring in concentrations of nutrient should be enhanced in ARB. Besides recognizing the processes and pathways accountable for groundwater pollution as well as pinpointing the problematic areas of actions could be targeted, hence, the modelling framework presented in our research could support the scenario analysis, as internal responses between groundwater and its determinant parameters are considered. Therefore, SWAT model results could support the development of indicators of water quality parameters with groundwater in a nexus thinking approach with reference to the SDGs of the UNs $[62,67]$. A limitation of this specific study was limited availability of observed input data, which could assist with better representing the distribution, which resulted for some sort of errors during modeling process in the river basin. However, a reliable sate of the art information of groundwater and nutrient fluxes in the ARB were therefore provided to be used for evaluating the effect of best management practices and used to support to the implementation better management practices.

\subsection{Consideration about groundwater nutrient pollution}

Athabasca River Basin is providing numerous services including industrial, agriculture, fisheries, and drinking water supply. Such intensive water uses put several burdens on groundwater quality influencing the ecosystem and polluting huge parts of the Athabasca River Basin. Our study of groundwater quality modelling allowed in detecting the impact of diffused and point and nonpoint sources of pollutants. Percolation of elevated sources of $\mathrm{NO}_{3}{ }^{-}$, and TDS into the groundwater and diffuse in the form of lateral flow hence affecting the quality of groundwater. Particularly, the use of fertilizers, manure, and industrial wastes significantly contributes to the pollution of groundwater.

\section{Conclusions}

Groundwater is the precious natural resource for the existence of life on earth. However, various factors, viz., various soil properties, crop development, industrial wastes, and agriculture 
influenced its quality. It is difficult to predict groundwater quality using the existing SWAT model due to inadequate representation of complex interaction of surface water and groundwater. In our study, we extended the existed SWAT model to better represent groundwater quality through considering water carrying capacity of quality parameters (i.e. $\mathrm{NO}_{3}{ }^{-}$and TDS). A systematic calibration and validation techniques of SWAT model has been performed to compare the observed groundwater $\mathrm{NO}_{3}{ }^{-}$and TDS fluxes in the ARB. The simulated results illustrate, the modified SWAT model performed well, albeit at some point the concentrations were underestimate and overestimate. As per the model performance comparison, the results reviled that the new groundwater quality model in the SWAT is able to capture the daily nutrient concentrations of groundwater. Thus, the process-based hydrologic groundwater quality model is an effective tool in simulating the groundwater quality dynamics $\left(\mathrm{NO}_{3}{ }^{-}\right.$and TDS) for sustainable groundwater and surface water management in the river basin.

\section{Conflict of interest}

The authors confirmed there is not conflict of interest.

\section{Acknowledgements}

The authors acknowledge to the Alberta Economic Development and Trade for the Campus Innovates Program Research Chair for the financial support (No. RCP-12-001-BCAIP). We are grateful to thank to Dr. Diogo Sayanda, Mike Coffill and Alex Blanchette for providing the groundwater data for the Athabasca River Basin.

\section{References}

1. Papaioannou, A., Dovriki, E., Rigas, N., Plageras, P., Rigas, I., Kokkora, M., Papastergiou, P., 2010. Assessment and modelling of groundwater quality data by environmetric methods in the context of public health. Water resources management, 24(12), 3257-3278.

2. García-Díaz, J.C., 2011. Monitoring and forecasting nitrate concentration in the groundwater using statistical process control and time series analysis: a case study. Stochastic Environmental Research and Risk Assessment, 25(3), 331-339. 
3. Khadri, S.F.R., Pande, C., 2016. Ground water flow modeling for calibrating steady state using MODFLOW software: a case study of Mahesh River basin, India. Modeling Earth Systems and Environment, 2(1), p.39.

4. Moharir, K., Pande, C., Patil, S., 2017. Inverse modelling of aquifer parameters in basaltic rock with the help of pumping test method using MODFLOW software. Geoscience Frontiers, 8(6), pp.1385-1395.

5. Morris, B.L., Lawrence, A.R., Chilton, P.J.C., Adams, B., Calow, R.C., Klinck, B.A., 2003. Groundwater and its susceptibility to degradation: a global assessment of the problem and options for management (Vol. 3). United Nations Environment Programme.

6. Siebert, S., Burke, J., Faures, J.M., Frenken, K., Hoogeveen, J., Döll, P., Portmann, F.T., 2010. Groundwater use for irrigation - a global inventory. Hydrology and earth system sciences, 14(10), 1863-1880.

7. Goovaerts, P., AvRuskin, G., Meliker, J., Slotnick, M., Jacquez, G. and Nriagu, J., 2005. Geostatistical modeling of the spatial variability of arsenic in groundwater of southeast Michigan. Water Resources Research, 41(7).

8. Coynel, A., Schäfer, J., Dabrin, A., Girardot, N., Blanc, G., 2007. Groundwater contributions to metal transport in a small river affected by mining and smelting waste. Water research, 41(15), 3420-3428.

9. Williams, J.R., Hann, R.W., 1978. Optimal operation of large agricultural watersheds with water quality restraints. Texas Water Resources Institute.

10. Singh, A.K., Patel, S., Singh, S.K., 2018. Groundwater quality assessment and its suitability for drinking purposes in Sonbhadra District, UP, India. Integrated Natural Resource Management: The Way Forward.

11. Jacintha, T.G.A., Rawat, K.S., Mishra, A., Singh, S.K., 2017. Hydrogeochemical characterization of groundwater of peninsular Indian region using multivariate statistical techniques. Applied Water Science, 7(6), 3001-3013.

12. Srivastava, P.K., Pandey, P.C., Kumar, P., Raghubanshi, A.S., Han, D., 2016. Appraisal of Surface and Groundwater of the Subarnarekha River Basin, Jharkhand, India: Using Remote Sensing, Irrigation Indices and Statistical Technique. In Geospatial Technology for Water Resource Applications (pp. 160-185). CRC Press. 
13. Nemčić-Jurec, J., Singh, S.K., Jazbec, A., Gautam, S.K., Kovač, I., 2019. Hydrochemical investigations of groundwater quality for drinking and irrigational purposes: two case studies of Koprivnica-Križevci County (Croatia) and district Allahabad (India). Sustainable Water Resources Management, 5(2), 467-490.

14. Oyarzun, R., Arumí, J., Salgado, L., Mariño, M., 2007. Sensitivity analysis and field testing of the RISK-N model in the Central Valley of Chile. Agricultural water management, 87(3), 251-260.

15. Srivastava, P.K., Singh, S.K., Gupta, M., Thakur, J.K., Mukherjee, S., 2013. Modeling impact of land use change trajectories on groundwater quality using remote sensing and GIS. Environmental Engineering \& Management Journal (EEMJ), 12(12), 2343-2355.

16. Kumar, N., Singh, S.K., Pandey, H.K., 2018. Drainage morphometric analysis using open access earth observation datasets in a drought-affected part of Bundelkhand, India. Applied Geomatics, 10(3), 173-189.

17. Roselló, M.P., Martinez, J.V., Navarro, B.A., 2009. Vulnerability of human environment to risk: case of groundwater contamination risk. Environment International, 35(2), 325-335.

18. Jacintha, T.G.A., Rawat, K.S., Mishra, A. and Singh, S.K., 2017. Hydrogeochemical characterization of groundwater of peninsular Indian region using multivariate statistical techniques. Applied Water Science, 7(6), pp.3001-3013.

19. Pardo-Igúzquiza, E., Dowd, P., Bosch, A.P., Luque-Espinar, J.A., Heredia, J., DuránValsero, J.J., 2018. A parsimonious distributed model for simulating transient water flow in a high-relief karst aquifer. Hydrogeology Journal, 26(8), 2617-2627.

20. Younes, A., Zaouali, J., Lehmann, F., Fahs, M., 2018. Sensitivity and identifiability of hydraulic and geophysical parameters from streaming potential signals in unsaturated porous media. Hydrology and Earth System Sciences, 22(7), 3561-3574.

21. Eckhardt, K., Haverkamp, S., Fohrer, N., Frede, H.G., 2002. SWAT-G, a version of SWAT99. 2 modified for application to low mountain range catchments. Physics and Chemistry of the Earth, Parts $A / B / C, 27(9-10), 641-644$.

22. Vazquez-Amábile, G.G., Engel, B.A., 2005. Use of SWAT to compute groundwater table depth and streamflow in the Muscatatuck River watershed. Transactions of the ASAE, 48(3), 991-1003. 
23. Luo, Y., He, C.S., Sophocleous, M., Yin, Z., Hongrui, R., Ouyang, Z., 2008. Assessment of crop growth and soil water modules in SWAT2000 using extensive field experiment data in an irrigation district of the Yellow River basin. Journal of Hydrology, 352(1-2), 139-156. doi: 10.1016/j.jhydrol.2008.01.003.

24. Baffaut, C., Benson, V.W., 2009. Modeling flow and pollutant transport in a karst watershed with SWAT. Transactions of the ASABE, 52(2), 469-479.

25. Watson, B.M., McKeown, R.A., Putz, G., MacDonald, J.D., 2008. Modification of SWAT for modelling streamflow from forested watersheds on the Canadian Boreal Plain. Journal of Environmental Engineering and Science, 7(S1), 145-159.

26. McKeown, R., Putz, G., Arnold, J., Di Luzio, M., 2005, July. Modifications of the Soil and Water Assessment Tool (SWAT-C) for streamflow modeling in a small, forested watershed on the Canadian boreal plain. In Proc. 3rd International SWAT Conf (pp. 189-199).

27. Melaku, N.D., Wang, J., 2019. A modified SWAT module for estimating groundwater table at Lethbridge and Barons, Alberta, Canada. Journal of Hydrology, 575, 420-431.

28. Meshesha, T.W., Wang, J., Melaku, N.D., 2020a. The modified Hydrological model for assessing effect of $\mathrm{pH}$ on fate and transport of Escherichia coli in the Athabasca River Basin. Journal of Hydrology, 582, 124513.

29. Meshesha, T.W., Wang, J., Melaku, N.D., 2020b. Modelling spatiotemporal patterns of water quality and its impacts on aquatic ecosystem in the cold climate region of Alberta, Canada. Journal of Hydrology, 587, 124952.

30. Kim, N.W., Chung, I.M., Won, Y.S., Arnold, J.G., 2008. Development and application of the integrated SWAT-MODFLOW model. Journal of hydrology, 356(1-2), 1-16.

31. Guzman, J.A., Moriasi, D.N., Gowda, P.H., Steiner, J.L., Starks, P.J., Arnold, J.G., Srinivasan, R., 2015. A model integration framework for linking SWAT and MODFLOW. Environmental Modelling \& Software, 73, 103-116.

32. Nguyen, V.T., Dietrich, J., 2018. Modification of the SWAT model to simulate regional groundwater flow using a multicell aquifer. Hydrological processes, 32(7), 939-953.

33. Ng, G.H., Wickert, A.D., Somers, L.D., Saberi, L., Cronkite-Ratcliff, C., Niswonger, R.G., McKenzie, J.M., 2018. GSFLOW-GRASS v1.0.0: GIS-enabled hydrologic modeling of coupled groundwater-surface-water systems. Geosci. Model Dev. 11, 4755-4777. 
34. Wang, J., Li, Y., Bork, E.W., Richter, G.M., Eum, H.-II, Chen, C., Shah, S.H.H., Mezbahuddin, S., 2020. Modelling spatio-temporal patterns of soil carbon and greenhouse gas emissions in grazing lands: Current status and prospects. Science of The Total Environment, 739, 139092.

35. AWC (2013). State of the Watershed Report: Phase 3 - Water Quantity and Basic Water Quality in the Athabasca Watershed. Athabasca Watershed Council.

36. AWC (2011). Athabasca Watershed Council - State of the Watershed Report: Phase 1. Athabasca Watershed Council, Hilton, Alberta.

37. Dibike, Y., Eum, H.I. \& Prowse, T., 2018. Modelling the Athabasca watershed snow response to a changing climate. Journal of Hydrology: Regional Studies, 15, 134-148. https://doi.org/10.1016/j.ejrh.2018.01.003.

38. Shrestha, N.K., Du, X., Wang, J., 2017. Assessing climate change impacts on fresh water resources of the Athabasca River Basin, Canada. Science of The Total Environment 601, 425-440.

39. Worku, T., Khare, D., Tripathi, S.K., 2017. Modeling runoff-sediment response to land use/land cover changes using integrated GIS and SWAT model in the Beressa watershed. Environmental earth sciences, 76(16), 550.

40. Neitsch, S.L., Arnold, J.G., Kiniry, J.R., Williams, J.R., 2011. Soil and water assessment tool theoretical documentation version 2009. Texas Water Resources Institute.

41. Halefom, A., Sisay, E., Khare, D., Singh, L., Worku, T., 2017. Hydrological modeling of urban catchment using semi-distributed model.Modeling Earth Systems and Environment, 3(2), pp.683-692.

42. Sisay, E., Halefom, A., Khare, D., Singh, L., Worku, T., 2017. Hydrological modelling of ungauged urban watershed using SWAT model. Modeling Earth Systems and Environment, 3(2), 693-702.

43. Shrestha, N.K., Wang, J., 2020. Water Quality Management of a Cold Climate Region Watershed in Changing Climate. Journal of Environmental Informatics, 35 (1), 56-80.

44. Neitsch, S.L., Arnold, J.G., Kiniry, J.R., Williams, J.R. and King, K.W., 2005. Soil and water assessment tool theoretical documentation version 2005. Grassland. Soil and Water Research Laboratory, Blackland Research Center, Temple, Texas. 
45. Melaku, N.D., Wang, J., Meshesha, T.W., 2020a. Improving hydrologic model to predict the effect of snowpack and soil temperature on carbon dioxide emission in the cold region peatlands. Journal of Hydrology, p.124939.

46. Melaku, N.D., Shrestha, N.K., Wang, J., Thorman, R., 2020b. Predicting nitrous oxide emissions following the application of solid manure to grassland in the United Kingdom. Journal of Environmental Quality, 49 (1), 1-13.

47. Lam, Q.D., Schmalz, B., Fohrer, N., 2010. Modelling point and diffuse source pollution of nitrate in a rural lowland catchment using the SWAT model. Agricultural Water Management, 97(2), 317-325.

48. Motsinger, J., Kalita, P., Bhattarai, R., 2016. Analysis of best management practices implementation on water quality using the soil and water assessment tool. Water, 8(4), 145.

49. Rolff, C., Almesjö, L., Elmgren, R., 2007. Nitrogen fixation and abundance of the diazotrophic cyanobacterium Aphanizomenon sp. in the Baltic Proper. Marine Ecology Progress Series, 332, 107-118.

50. McElroy, A.D., 1976. Loading functions for assessment of water pollution from nonpoint sources (Vol. 1). US Environmental Protection Agency, Office of Research and Development, [Office of Air, Land, and Water Use].

51. Brown, L.C. and Barnwell, T.O., 1987. The enhanced stream water quality models QUAL2E and QUAL2E-UNCAS: Documentation and user manual (p. 189). EPA.

52. Almasri, M.N., 2007. Nitrate contamination of groundwater: A conceptual management framework. Environmental Impact Assessment Review, 27(3), 220-242.

53. Fisher, R.S., Davidson, O.B., Goodman, P.T., 2004. Summary and Evaluation of Groundwater Quality in the Upper Cumberland, Lower Cumberland, Green, Trade water, Tennessee, and Mississippi River Basins. Kentucky Geological Survey, University of Kentucky.

54. Shao, G., Zhang, D., Guan, Y., Xie, Y. Huang, F., 2019. Application of SWAT model with a modified groundwater module to the semi-arid Hailiutu River Catchment, Northwest China. Sustainability, 11(7), 2031.

55. Abbaspour, K.C. and Vedjani, M., 2007. SWAT-CUP Calibration and Uncertainty Programs for SWAT. MODSIM07: Land. Water and Environmental ManagementIntegrated Systems for Sustainability. Christchurch, New Zealand, pp.1-7. 
56. Chen, H., Luo, Y., Potter, C., Moran, P.J., Grieneisen, M.L., Zhang, M., 2017. Modeling pesticide diuron loading from the San Joaquin watershed into the Sacramento-San Joaquin Delta using SWAT. Water research, 121, 374-385.

57. Moriasi, D.N., Gitau, M.W., Pai, N., Daggupati, P., 2015. Hydrologic and water quality models: Performance measures and evaluation criteria. Transactions of the ASABE, 58(6), 1763-1785.

58. Du, X., Shrestha, N.K., Ficklin, D.L. and Wang, J., 2018. Incorporation of the equilibrium temperature approach in a Soil and Water Assessment Tool hydroclimatological stream temperature model. Hydrology and Earth System Sciences, 22(4), p.2343.

59. Arnold, J.G., Moriasi, D.N., Gassman, P.W., Abbaspour, K.C., White, M.J., Srinivasan, R., Santhi, C., Harmel, R.D., Van Griensven, A., Van Liew, M.W. and Kannan, N., 2012. SWAT: Model use, calibration, and validation. Transactions of the ASABE, 55(4), pp.1491-1508.

60. Haas, M.B., Guse, B., Pfannerstill, M., Fohrer, N., 2015. Detection of dominant nitrate processes in ecohydrological modeling with temporal parameter sensitivity analysis. Ecological modelling, 314, 62-72.

61. Panuska, J.C. and Robertson, D.M., 1999. Estimating phosphorus concentrations following alum treatment using apparent settling velocity. Lake and Reservoir Management, 15(1), pp.28-38.

62. Me, W., Abell, J.M. and Hamilton, D.P., 2015. Effects of hydrologic conditions on SWAT model performance and parameter sensitivity for a small, mixed land use catchment in New Zealand. Hydrology \& Earth System Sciences, 19(10).

63. Vigiak, O., Malagó, A., Bouraoui, F., Vanmaercke, M., Obreja, F., Poesen, J., Habersack, H., Fehér, J., Grošelj, S., 2017. Modelling sediment fluxes in the Danube River Basin with SWAT. Science of the Total Environment, 599, 992-1012.

64. Longe, E.O., Enekwechi, L.O., 2007. Investigation on potential groundwater impacts and influence of local hydrogeology on natural attenuation of leachate at a municipal landfill. Int. J. Environ. Sci.Technol., 4(1), 133-140.

65. Mor, S., Ravindra, K., Dahiya, R.P., Chandra, A., 2006. Leachate characterization and assessment of groundwater pollution near municipal solid waste landfill site. Environmental monitoring and assessment, 118(1-3), 435-456. 
66. WHO, H.I.D.W.B., 2003. Document for Preparation of Who Guidelines for DrinkingWater Quality. Geneva. World Health Organization (Who/Sde/Wsh/03.04/12).

67. Malagó, A., Bouraoui, F., Vigiak, O., Grizzetti, B., Pastori, M., 2017. Modelling water and nutrient fluxes in the Danube River Basin with SWAT. Science of the Total Environment, 603, 196-218.

68. Giupponi, C. and Gain, A.K., 2017. Integrated spatial assessment of the water, energy and food dimensions of the sustainable development goals. Regional Environmental Change, 17(7), pp.1881-1893. 